\title{
Nyai Ontosoroh: a Female Hero and Her Resistance to Gender Injustice
}

\author{
Budi Waluyo*, Andrik Purwasito, Warto, Slamet Subiyantoro \\ Fakultas Keguruan dan Ilmu Pendidikan, Universitas Sebelas Maret, Indonesia \\ *mas_bewe@yahoo.co.id
}

DOI: 10.20884/1.jli.2021.12.2.3538

\begin{abstract}
Article History:
First Received:

ABSTRACT

$23 / 11 / 2020$

Final Revision:

Nyai Ontosoroh is a character in Pramudya Ananta Toer's novel Bumi Manusia, which depicts a woman's struggle against injustice in her life. $R$. Giryadi adapted Nyai Ontosoroh's struggle in this novel into a short

$12 / 09 / 2021$

Available online: drama titled "Nyai Ontosoroh." The plot of this drama revolves around Nyai Ontosoroh's opposition to her husband and the Dutch government, which wants to take over the company and custody of her child. A Javanese woman's resistance to the colonial government was courageous

$31 / 12 / 2021$ at the time. Despite being defeated, Nyai Ontosoroh had fought for his rights in a dignified manner. She deserved to be referred to as a "hero." The purpose of this study is to explain and describe the various forms of gender injustice against women in R. Giryadi's drama script "Nyai Ontosoroh." This study is descriptive qualitative in nature. It is tailored to the formulation of determined research problems. It is a qualitative study that is thoroughly and analytically described. Forms of gender injustice against women are described. The conclusion of this paper indicates that women in Indonesia continue to face numerous gender injustices. Women must fight for gender equality as they should.
\end{abstract}

Keywords: drama; resistance; gender injustice; female hero

\section{INTRODUCTION}

Literature is a social reflection. It is created as a fictional expression of people's lives. Drama is one type of literary work that reflects people's lives. The drama captures real-life events. It was created to depict and criticize what happened in society. Drama is a staged depiction of human life. Sometimes the conflicts depicted in the drama are similar to their inner conflicts. Drama is a portrait of human life, a portrait of joy and sorrow, with their black and white experiences (Renggani, 2014).

There are heroic characters that stand out in several dramatic literary works. This hero holds a significant place in literature. According to Ross (2019), a hero is someone who carries the spirit, enlivens the heart, enlightens the mind, and has the courage to get up and move. What 
he/she does has the potential to inspire others. In literature, it is defined as someone who has a strong desire to protect others and the courage to confront evil.

Giryadi's Nyai Ontosoroh drama is based on Pramoedya Ananta Toer's novel Bumi Manusia, an outstanding and prolific Indonesian writer. Master Mellema's concubine is referred to as Nyai Ontosoroh. However, there is one thing that sets Nyai Ontosoroh apart from the average concubine. Nyai Ontosoroh is described as a concubine who refuses to accept her fate. Despite her status as a nyai, Nyai Ontosoroh is eager to learn to read, write, and even speak Dutch. In colonial period, nyai was the name given to a European man's concubine. According to Linda Christanty, a governor of the Java allegedly has twenty local native women, "nyai" (in Irenewaty, 2016).

She is also proficient in office administration and meticulous in all business matters. In short, Nyai Ontosoroh is a manifestation of indigenous women who are far ahead of that time. Being a nyai and having that attribute, according to her, is nothing to be ashamed of, and that is how she prefers to be addressed. She is neither a typical mistress nor a typical nyai. Nyai Ontosoroh, on the other hand, is described as a typical indigenous woman who is intelligent, tough, assertive, and self-sufficient. Nyai Ontosoroh is described as a woman who fights for her destiny in the face of colonialism. At the same time, she is never afraid to express herself freely and openly.

Nyai Ontosoroh's status as a "female hero" implies that she is capable of enlightenment and the courage to rise and change her fate. As Tandian (2021) stated that a hero is someone who is willing to make a sacrifice for the sake of others. Not only men, but also women, can be considered as a hero. Her life as a nyai, which began with coercion, did not necessarily lead to a long-term decline. Her desire to be free of various, especially gender, injustices has shaped and transformed her into a fighter with the courage and passion for fighting back. According to Fakih (2008), gender injustice is a system or structure that causes both men and women to be victims. Gender injustice takes many forms, including marginalization, subordination, and violence.

Nyai Ontosoroh's inspiring story prompted researchers to conduct a study on Nyai Ontosoroh's heroism. The discussion will be divided into two parts. The first section will discuss the gender injustice she has experienced, and then followed by a discussion of her resistance to eliminate the gender injustice. 


\section{MATERIALS AND METHOD}

This research is a qualitative study that employs descriptive methods. A descriptive method is a way of looking at a group of people, an object, a condition, a system of thought, or a series of events in the present (Nazir, 2005: 54). The descriptive method is capable of producing systematic, factual, and accurate descriptions of facts investigated in drama analysis. This method is used because it allows researchers to gather comprehensive information about a phenomenon. In this case, the researcher collected, categorized, and analyzed the collected data. It appears in the form of narrative and dialogue quotes in Nyai Ontosoroh's drama script. It describes Nyai Ontosoroh's gender injustice and her resistance to Europeans during the colonial period as a concubine.

This research was broken down into several steps. The researcher's first step is to collect, categorize, and analyze the data that has been gathered. The data is in the form of narrative and dialogue quotes from Nyai Ontosoroh's drama script, which describes Nyai Ontosoroh's gender injustice and resistance as a European concubine during the colonial period. The researcher then used the data that was gathered to respond to the previously formulated questions.

\section{RESULTS \& DISCUSSION}

The main issue in Nyai Ontosoroh's drama was her own father's "selling" of Sanikem. The motivation for this action was greed for a high position. Sastrotomo (Sanikem's father) had been deceived into selling his own daughter to Tuan Besar Mellema by the allure of being promoted from clerk to paymaster (a Dutchman). Sanikem's "sale" to Tuan Besar Mellema had elevated her status to a European concubine. The status of a concubine, which she obtained through coercion, caused her to lose her identity gradually. She had the impression that Sanikem had faded away and had been replaced by the figure of Nyai Ontosoroh.

Because of her status as a concubine, she received a variety of unpleasant treatment from society. She was thought to be an immoral woman. A concubine was considered the same as a mistress who was not legally married. Being a concubine entails sacrificing one's entire body and soul to the master.

Nyai Ontosoroh's story did not end with the various injustices she had suffered. Everything she had gone through was only the beginning of her life as a nyai. The various injustices she had suffered served as catalysts for her to fight back and stand on her own two feet. Tuan Besar Mellema had provided her with the opportunity to study, and she did not waste it. She worked hard in school, was able to read and write, and was fluent in Dutch. 
She was even considered to be capable of outperforming most educated Dutch women as a concubine. Tuan Besar Mellema admitted it himself when asked by nyai whether she was like a Dutch woman.

Ha..ha..ha.. tak mungkin kau seperti wanita Belanda. Juga tidak perlu. Kau cukup seperti sekarang. Kau lebih mampu dari rata-rata mereka. Apalagi yang peranakan (Giryadi, 2007).

Ha .. ha .. ha .. there's no way you're like a Dutch woman. Nor is it necessary. Just be you

like now. You're more capable than them in average, especially the half-breed (Giryadi, 2007).

Nyai Ontosoroh's resistance included mastering various subjects through study and accomplishing Tuan Besar Mellema's business operations. He delegated responsibility to her. In matters of business, she proved that Tuan Besar Mellema valued her opinion. She took part in completing Tuan Mellema's duties.

Nyai Ontosoroh's actions as a concubine deserve to be referred to as a "female hero" for a variety of reasons. As previously stated, nyai takes advantage of any learning opportunities that come her way. Mr. Mellema's awareness of the value of knowledge will provide her with the means to continue learning until she is given the confidence to take over the Mellema's business. She became a loyal and obedient nyai, but she also remained tough and firm, making Mellema rely on her. Because of her concubine status, she was unable to be released from the shackles that bound her. She also couldn't fight for her child's rights. Even though she was defeated, her actions demonstrated that she was not an ordinary concubine. She possessed a special ability that no other concubine possessed. She was more courageous, demonstrated her ability and determination, and did not give up fighting for what was rightfully hers.

\section{Gender Injustice}

Sanikem, later known as Nyai Ontosoroh, had been subjected to a slew of gender injustices from the start. Starting with her father (Sastrotomo) selling her to a rich man for the sake of satisfying his greed, nyai was subjected to a slew of insults as a result of her status as a concubine. 
Takada kata pilihan! Pemuda-pemuda melarat dan kampungan, tak patut untuk dipilih. Yang ada sekarang kau dipilih untuk menjadi istri seorang yang kaya raya. Siapapun orangnya! (Giryadi, 2007).

There is no other choice! Those poor men, don't deserve to be chosen. Now you are chosen to be the wife of a rich man. Whoever it is! (Giryadi, 2007).

Nyai's desire to pick her own future husband was met with opposition from her father from the start. He didn't want to know about Nyai's decision because he was the only one who could decide whom she would marry and when she would marry. As Jin \& Xu (2004: 4) thought, in parental involved marriages, parent assign or introduce potential candidate(s) to their children. It was the parents who introduced potential candidates to their child in marriages. Sanikem's mother was powerless to intervene, even though their daughter disagreed. She initially agreed with Sastrotomo's wishes because she was worried that Sanikem would be labeled a spinster.

Tabahkan hatimu, Nak. Usiamu sudah 14 tahun. Kau sudah haid. Tidak baik kau dikatakan perawan kaseb. Maka relakan hari mudamu (Giryadi, 2007).

Be strong, my daughter. You are already 14 years old. You have got your period. It's not good to say that you are a spinster. So give up your youth. (Giryadi, 2007)

Sanikem's mother was concerned that her daughter would become a gossip among her neighbors for not marrying when she was in marriageable age. According to Puspitasari et al. (2019), the decision to get married early is strongly influenced by the culture of shame as a result of the neighbor's gossip if the marriage is not done immediately to the daughter. The cultural judgment that a girl should marry early or risk being labeled a spinster heavily influenced the decision to marry early. It's not only made a girl afraid of marrying in her old age, but it also made the girl's family afraid of becoming the gossip of the neighbors. This condition demonstrated how society treated women differently than men.

A spinster label is a form of gender injustice against women. This is due to the fact that if a woman does not marry, she will be gossiped about and insulted in society. It is, however, a natural case for men. Nobody refers to a man as a bujang tua (old bachelor); in fact, there is an proverb that the older a man is, the more mature and better he is. 
As in most Javanese families, the father is the family's leader and appears to have the authority to make all decisions. The same thing happened in Sanikem's case. When her father discovered that Sanikem had married Tuan Besar Mellema for the sake of wealth, her mother was about to defend her.

Kamu jangan banyak omong! (Giryadi, 2007).

You stop talking! (Giryadi, 2007).

The father's order demonstrated that women did not have the right to participate in discussing and making decisions in the Sanikem family. According to Rini (2019), Javanese women were positioned as konco wingking (only concerned with bed and kitchen issues) and swarga nunut neraka katut (if the husbands go to heaven, the wives will follow and if the husbands go to hell women also follow). In other words, Javanese women only had the right to manage internal household matters such as bed and kitchen affairs and did not have the authority to participate in determining external affairs. According to Soeharto et al. (2019), the paradigm of women's roles has remained relatively unchanged, with most people still expecting women to care for the home. That is, there are still many people who believe that women do not need to take care of external matters such as working and protecting families; instead, women only need to obey their husbands and take care of kitchen matters. This statement is supported by Shokri and Asl (2015), men are stereotyped as dominant and aggressive, whereas women are stereotyped as caring, loving, and submissive. These stereotypes of masculinity and femininity are not only social constructs, but have also been internalized by both men and women. While men are expected to work and care for their families, women are expected to do menial tasks and care for their children and even other family members.

Nyai Ontosoroh, as an engaged woman, was also forbidden from leaving the house and meeting with other men. She had to follow her father's instructions.

Ikem telah mendapatkan laki-laki yang pantas. Mulai saat ini Sanikem tidak boleh keluar rumah. Tidak boleh memandang ke laki-laki yang berkeliaran dan tidak jelas itu (Giryadi, 2007). 
Ikem has found the man she deserves. From now, Sanikem is not allowed to leave the house. She cannot see other man who just hanging around the neighborhood. (Giryadi, 2007).

The words of Nyai Ontosoroh's father, Sastrotomo, indicate male dominance. Sanikem is not permitted to simply leave the house. She went through a process known as seclusion. Pingitan (seclusion) is a Javanese cultural practice. The bride-to-be is not permitted to leave the house during the wedding preparations. This tradition demonstrates how women are viewed as deserving of more restrictions than men. There are numerous restrictions against women leaving the house, which occurred not only during the colonial period, but also today.

Nyai Ontosoroh told Annelies, her daughter, about her past experiences. She went into great detail about the gender injustice she had experienced as a result of his father's treatment.

Saya tidak punya hak untuk menentukan masa depan saya. Semua telah ditentukan oleh ayah saya. Mamamu hanya bisa menunggu datangnya laki-laki yang akan mengambilnya dari rumah, entah kemana, entah sebagai istri nomor berapa, pertama atau ke empat. Ayah saya dan hanya ayah saya yang menentukan. Apakah yang mengambil seorang lakilaki tua atau muda, seorang perawan tidak berhak tahu. Sekali peristiwa itu terjadi, perempuan harus mengabdi dengan seluruh jiwa dan raganya pada laki-laki tak dikenal itu, seumur hidup, sampai mati atau sampai dia bosan dan mengusirnya. Tak ada pilihan. Boleh jadi mereka yang datang seorang penjahat, penjudi, atau pemabuk. Orang takkan bakal tahu sebelum menjadi istrinya. Akan beruntung bila yang datang itu seorang budiman dan belum beristri. (Giryadi, 2007).

I have no right to make decisions about my own future. My father has made all of the decisions. Your mother is only waiting for the man who will take me from the house, whether as the first or fourth wife. Everything is decided solely by my father. A virgin has no right to know whether the person who is taking me is an old or young man. Once such an event occurs, a woman is obligated to devote her entire body and soul to this unknown man for the rest of her life, until she dies or until he gets bored and throws her out. There is no option. It's possible that those who came were criminals, gamblers, or drunks. Nobody will ever know unless they marry him. (Giryadi, 2007). 
Even in the smallest community, the family, women do not have the same status. The Nyai Ontosoroh's family is just one of many similar cases in which women are always regarded as marginal or second-class citizens who must obey men's commands. Even today, many problems arise as a result of husband's desire to be seen as more dominant and respected.

\section{Women's Resistance}

The various gender injustices experienced by the character Nyai Ontosoroh from her teenage until she had two children. It did not make nyai abandon her faith. Beginning with being sold to a Dutchman, she worried about being labeled as a spinster, living by enduring her father's dominance, until she gave her entire body and soul to the master who bought it. She became a strong and independent woman as a result of the various gender injustices. Nyai was determined to make her own decisions in life from the beginning. She refused her father's plan to match her with a wealthy man.

Betul saya sudah dewasa, tetapi sayapun berhak untuk menentukan pilihan (Giryadi, 2007).

It is true that I already an adult, but I have the right to make choices (Giryadi, 2007).

Her father opposed her right to choose her own future husband, so she struggled to assert her right to do so. However, it was only the beginning of her struggles. Later, she became a hero to herself and her children. She took Tuan Besar Mellema's request to study and start taking care of business seriously to fight for her rights.

Ya, saya akan menjalankan semua tugas sebaik-baiknya. Akan saya kerahkan seluruh tenaga dan perasaan yang ada di diri saya untuk Tuan. Sebaik-baiknya. Karena itulah tugas saya, sebagai Nyai Tuan. Apakah wanita Eropa diajar sebagaimana saya diajar sekarang ini, Tuan? Sudahkah saya seperti wanita Belanda? (Giryadi, 2007).

Yes, I will carry out all duties as well as possible. I will devote all my energy and feelings to you. I will do the best. It is because that's my job, as your nyai. Were European women being taught the way I am today, sir? Have I been like a Dutch woman? (Giryadi, 2007). 
All of nyai's statement shows that Nyai Ontosoroh was a woman who could do a variety of jobs. Not only she become responsible for household matters, but she also had some expelled employers. She is also mastered business and has studied languages and a variety of other subjects. She defied the stereotype that women are only good at cooking and cannot handle other responsibilities, such as running a business. Nyai demonstrated that women, like men, could handle a variety of tasks. Nyai Ontosoroh, a woman who had suffered many injustices at the hands of men, did not want to rely on men for her survival. That is why she attempted to become a wise and self-sufficient woman.

Segala yang saya pelajari selama hidup bersama TB Mellema, telah sedikit mengembalikan harga diri saya. Tetapi sikap saya tetap, mempersiapkan diri untuk tidak lagi tergantung dengan siapa pun. Tentu saja sangat berlebihan seorang perempuan Jawa berbicara tentang harga diri, apalagi, orang seperti saya yang masih begitu muda untuk berkeluarga. Begitulah akhirnya saya mengerti, saya tidak bergantung pada TB Mellema. Sebaliknya dia sangat tergantung pada saya. Saya telah mengambil sikap untuk ikut menentukan perkara. Tuan tidak pernah menolak. Bahkan ia sangat memaksa saya untuk terus belajar (Giryadi, 2007).

Everything, I learned during my life with TB Mellema has brought back my self-esteem a little. But my attitude remains, preparing myself not to depend on anyone anymore. Of course it is too much for a Javanese woman to talk about self-esteem, moreover, someone like me who is so young to have a family. That's how I finally understood; I'm not dependent on TB Mellema. On the contrary he is very dependent on me. I have taken a stand to be involved in deciding things and he, master, never refused. In fact, he really forced me to continue studying (Giryadi, 2007).

Nyai is one of the female characters who fights for her freedom, even though she does not want to be free of her concubine status. She does, however, have the freedom to learn, develop herself, and become an independent person without relying on others. This is demonstrated by her statement, "...but my attitude remains, preparing myself to no longer rely on anyone."

Not all women had the opportunity to learn at that time, even if it was just to read and write. The government purposefully prohibited natives from studying, especially girls, so that the government could continue to colonize and no natives had the intelligence to go against the Dutch government's will. Kartini wrote in her letter to Mejufrouw Zeehandelaar, "When the 
Javanese becomes educated, she will no longer say 'yes' to everything that her superiors suggest to her" (Sundari, 2019). After receiving an education, a Javanese woman would no longer agree to anything her superior ordered. Kartini also stated that one of the motivations for fighting against women's rights was a desire for freedom and independence (Sundari, 2019).

Nyai Ontosoroh had a daughter, Annelies, and she did not want her daughter to suffer the same fate as her. She gave her child a good education so that she could do the work that men normally did. Annelies was the foreman of the workers who looked after her family's cattle. She was not taught to be a woman who was reliant on men; rather, Nyai taught her to be a strong and independent woman. Furthermore, nyai gave her the freedom to choose her own path in life and who she would marry.

Jangan kau pikirkan apa-apa. Mama akan mengatur semua. Dan kau berhak menentukan akhirnya. Semua terserah kamu, Ann (Giryadi, 2007).

Never mind. Mama will manage everything. And you have the right to decide the end. It's all up to you, Ann (Giryadi, 2007).

Nyai's words shows that she had given her daughter the freedom to make her own life decisions. Nyai would assist Ann in making her wish come true. She did not want her daughter to live the same life as her, who had suffered a great deal of injustice as a result of her status as a concubine and as an indigenous woman.

Nyai Ontosoroh's struggle was not limited to her domestic issues. She also struggled the judicial law's determination that Annelies and Robert were only Tuan Besar Mellema's children.

Bukankah saya ibunya? Saya yang mengandung dan melahirannya. Saya yang merawat dan membesarkannya...? Ini adalah fakta...? Hukum tuan tidak mengakui saya sebagai Ibu dari anakku sendiri, hanya karena saya pribumi dan tidak kawin secara syah dengan Tuan. Ya, saya mengerti. Seharusnya saya tidak bertanya-tanya ini, tetapi, syah atau tidak menurut hukum Tuan, saya tetaplah ibu dari anak-anak saya. (Giryadi, 2007).

Am I not their mother? I was the one who pregnant and giving birth. I took care and raised them ...? This is a fact ...? Your law does not recognize me as a mother of my own children, only because I am a native and not legally married to Tuan. Yes, I understand. I 
shouldn't be wondering this, but, legal or not according to your law, I am still the mother of my children. (Giryadi, 2007).

Nyai was insisted that, despite the fact that the law stated that both Annelies and Robert were not her children, they were in fact her children. She didn't care if the law said otherwise. Nyai Ontosoroh demonstrated conclusively that women could fight oppression and rise up to be stronger. She was a hero in the form of a woman fighting for her rights and finding her own strength.

\section{CONCLUSION}

Based on the discussion above, it is clear that the injustices suffered by Nyai Ontosoroh continue to occur. Nyai Ontosoroh's various resistances have demonstrated that women can dominate and deserve to be referred to as female heroes. Nyai's abilities as a concubine exceed those of the average concubine. She is also said to be more capable than most Dutch women. She fights for women's rights with her abilities, including fully supporting her daughter Annelies in getting what she wants without prohibiting and interfering, as her parents did. Nyai also struggled to overcome the stereotype that women are only concerned with the domestic matters. She is a hero who fights for her rights and the rights of women in general.

\section{REFERENCES}

Fakih, M. (2008). Analisis Gender dan Transformasi Sosial. Yogyakarta: Pustaka Belajar.

Giryadi, R. (2007). Nyai Ontosoroh. Surabaya: Teater Institut Unesa

Irenewaty, T., \& Adhi, W. P. (2016). Eksistensi Perjuangan Wanita Masa Kolonial. 11 (2), 1331.

Jin, G. Z., \& Xu, L. C. (2004). Matchmaking Means and Marriage Quality: The Role Information in Marriage Markets. Departemen of Economics, University of Maryland, 1-45.

Nazir, M. (2005). Metode Penelitian. Jakarta: Ghalia Indonesia.

Puspitasari. (2019). Conformity of Javanese Cultural Values in Early Marriage: Case Study of Farmer Family Communication. International Journal of Multicultural and Multireligious Understanding, 6(2), 1-7. ISSN 2364-5369.

Renggani, (2014). Drama Radio: Penulisan dan Pementasan. Yogyakarta: Penebit Ombak.

Rini, P. C. (2019). Interpretasi Feminisme Tokoh Nyai Ontosoroh dalam Novel Bumi Manusia Tulisan Pramoedya Ananta Toer pada Komposisi Musik Ontosoroh karya Peni Candra Rini. GELAR: Jurnal Seni Budaya, 17(1), 24-30. 
Ross, S. L. (2019). Who Put the Super in Superhero? Transformation and Heroism as a Function of Evaluation. Frontiers in Psychology. Vol 09 (2514), 1 - 13, doi: 10.3389/fpsyg.2018.02514.

Shokri. (2015). Patriarchal Hierarchies of Power and the Subordination of Women: Real Doll as a Replacement of Woman Figure. Advances in Language and Literary Studies Vol. 6 No. 4; August 2015 ISSN: 22034714.

Soeharto, T.. (2020). The Description of Communal Sharing on Working Wives with Work-family Conflicts (Javanese Family): Indigenous Psycology Approach. Digital Press Social Sciences and Humanities 5:00012, 1-6.

Sundari, M. S. (2019). Raden Ajeng Kartini: Between Education and Feminism in Letters of Javanese Princess. Martabat: Jurnal Perempuan dan Anak, 3(2), 271-296). ISSN 2581-296.

Tandian, E. A. (2021). Perjalanan Pahlawan Perempuan Film Wonder Woman (2017) dan Mulan (2020): Kritik Feminisme terhadap Psikoanalisis. IMAJI: Film, Fotografi, Televisi, \&Amp; Media Baru, 12(1), 37-53. https://doi.org/10.52290/i.v12i1.15. 